groups are already in existence, and the formation of groups at a number of other centres is under consideration. Discussions at group meetings will not in general be published, but should the local group committee consider certain papers to be of sufficient importance, their publication and method of distribution will be considered. Meetings of the groups will be announced in the appropriate journals.

The Supplement to the Society's Journal is edited by the Committee of the Research Section under direction from the Council of the Society. It is hoped that, in addition to publishing papers read before the Research Section, it will become a medium for the publication of research work on topics of general interest to statisticians. Such papers need not necessarily be theoretical or mathematical but should expound or illustrate some new development in statistical methodology. At present, papers of this nature are often published in journals devoted to special branches of science and not always readily accessible to workers in other fields.

Membership of either or both Sections is open to fellows of the Society free of charge and to nonfellows who are approved by the appropriate Section Committee, on payment of an annual subscription of ten shillings (for each Section). The Supplement to the Journal will be published twice yearly. It will be available to fellows of the Society free of charge and to members of the Sections at reduced rates. Further information may be obtained from the Assistant Secretary, Royal Statistical Society, 4 Portugal Street, London, W.C.2.

\section{RESEARCH WORK AT THE MILLPORT MARINE LABORATORY*}

$\mathrm{T}$

HIS series of annual reports recently issued by the Scottish Marine Biological Association, covering as they do the war years $1939-44$, are of great interest. Not only has the work been well maintained, but also the new wing, representing a considerable extension of the laboratory buildings, opened in June 1939, has been in general use. The staff, in spite of several members being absent on war service, has been extremely active and, in addition, workers from out. side have added to the programme in various ways. This has been chiefly on the economic side, but ecological and faunistic work has still continued.

Dr. Orr's analysis of the various marine organisms with regard to their nutritive value, based on two hundred different species, including molluscs, crustaceans, fishes, cclenterates, echinoderms and worms, shows that molluses, crustaceans, fishes and worms are of high food value, echinoderms and cœlenterates low. The results have been tabulated. His more recent work has been chiefly an investigation of seaweeds with special attention to those likely to provide substitutes for Japanese agar. This research, later in collaboration with Dr. S. Marshall and throughout in close touch with representatives of the Ministries of Supply and Health, resulted in a satisfactory agar substitute being found in the red alga, Gigartina stellatus, which is now being used on a commercial scale. A survey of algæ is also being carried out.

Dr. S. Marshall, who in the early part of the period was occupied with the life-histories of certain cope-

* Annual Reports of the Scottish Marine Biological Association (1938-39, 39-40, 40-41, 41-42, 42-43, 43-44). (185 St. Vincent Street, Glasgow.) pods, besides this agar work, is, together with Dr. Orr and Dr. F. Gross and J. E. G. Raymont, of the University of Edinburgh, taking part in an interesting experiment in Loch Sween and its small arm Loch Craiglin, by fertilizing the water by the addition of nutrient salts and investigating the effect on the growth of the phyto- and zoo-plankton, and of the fish introduced. An account of this was given in Nature ${ }^{1}$. Latest reports show that the added nutrients were rapidly absorbed and an increase in the size of the fish was in many cases large.

The question as to the value of marine plankton as food for land animals was raised by Sir John Graham Kerr in 1941, and Prof. A. C. Hardy of Aberdeen, with the approval of the Agricultural Research Council, took the matter up and devised experiments in cooperation with the Millport Station, primarily to see if plankton could be obtained in sufficient quantities to be used to form an addition to protein meal for animal stock and poultry. Good samples of Calanus meal were prepared, but the results during the three years did not yield the hoped-for practical results, although Prof. Hardy regards it as a speculative investigation which was well worth trying as a possible additional source of protein in war-time.

In 1941, Dr. J. E. Harris, working under the Marine Corrosion Sub-Committee of the Iron and Steel Institute, began his researches at Millport on problems connected with the marine fouling of metals. This work has increased considerably and several assistants are now working at the various subjects, including the colonization of the experimental rafts with plant and animal growth. Much valuable information has been obtained in connexion with these researches, the technical side of which will be published in the reports of the Marine Corrosion Sub-Committee. On the biological side, among other points of interest, are K. A. Pyefinch's work on the barnacle larvæ and Dr. M. Mare's on the succession of algæ and on the part played by the bacterial slimes in the development of fouling growth.

Experiments on prawn trawling and on the production of seaweed meal were also made, and besides the work of direct economic importance ecological studies have continued, especially in Kames Bay, by Dr. A. C. Stephen and others, including the molluscan and crustacean fauna, the microfauna of the intertidal sands, and insect larvæ of the shore.

The food of the shag was investigated by A. J. Hadow and W. H. R. Lumby, who show close agreement with Steven's ${ }^{2}$ observations, the bird being of little economic importance.

1 Nature, 153, 483 (1944).

'J. Mar. Biol. Assoc., 19, 277.

\section{INDIAN PLYWOOD FOR TEA CHESTS}

$\mathrm{T}$ HE long stretch of country situated at the foot of the eastern Himalaya is occupied by a succession of tea gardens which extend up into the outer hills to some $5,000 \mathrm{ft}$. or so elevation on the west. Since the introduction of the growth of tea into the region, the necessary tea box or chest for packing and exporting the tea has been something of a problem with a varied history. In the supply of those gardens situated in Assam, saw mills were erected in Assam many years ago, but most of the chests required came 
in as imports from Europe in the form of shooks, battens and metal fittings, put together to form the chest on the spot.

This century has witnessed the advent of plywood and revolutionized the construction of the tea chests. In Indian Forest Records (New Series: Utilisation, Vol. 3, No. 4, Forest Research Institute, Dehra Dun, 1945), Mr. V. D. Limaye deals with "The Testing of Indian Plywood Tea Chests" with the object of establishing a standard type. With this objective in view, nine different types of plywood tea chests were subjected to systematic scientific tests at the Timber Testing Laboratory, with the view of establishing a standard tea chest of Indian make, comparable with the best of foreign makes. In India, plywood tea chests are manufactured from various timbers such as hollock (Terminalia myriocarpa), hollong (Dipterocarpus macrocarpus), mango (Mangifera indica), semul (Bombax malabaricum), pali, and others. Hollock is the main source of supply. It grows in the forests of Assam.

In the past, boxes of all these timbers have been subjected to systematic research at Dehra Dun. The series of exhaustive tests here described was carried out on nine different types of tea chests, known as the ' $O$ ', ' $S$ ' and ' $M$ ' types made chiefly of hollock timber with the view of analysing their comparative merits, and establishing a standard type of Indian plywood tea chest comparable with the best foreign makes. It would appear that this object has been fulfilled and that in this respect India at last can be considered as no longer dependent on imports. Boxes of each of the nine types, totalling in all 210, and representative of the average quality produced by the mill, were supplied in shook form by the Assam Saw Mills. The most common size of box, namely, 19 in. $\times 19$ in. $\times 24$ in., was chosen for the tests. In each of the ' $O$ ' and ' $S$ ' types, boxes of sizes 14 in. $\times$ 14 in. $\times 14$ in., 16 in. $\times 16$ in. $\times 16$ in., 18 in. $\times$ 18 in. $\times 18$ in., 18 in. $\times 12$ in. $\times 18$ in. were tested, the thickness of the veneers varying. In the ' $O$ ' type the plywood was all hollock. In the ' $S$ ' type the outside ply is of hollong (Dipterocarpus macrocarpus). In the ' $M$ ' type the outer ply is of semul. Boxes made with the side panels with the grain vertical are the strongest.

Summarizing the research work the following results are given : The ' $O$ ', 14 in. $\times 14$ in. $\times 14$ in., and ' $S$ ', 14 in. $\times 14$ in. $\times 14$ in., types of plywood tea-chest are found to be very much stronger than the average of the best five makes of imported birch tea-chests, taken as the datum for comparison. By reducing the thickness of plywood to $3 / 16$ in., it has been found that the cost of a tea-chest can be reduced, owing to economy in timber, without sacrificing the strength required. 18 in. $\times 12$ in. $\times 18$ in. type and 16 in. $\times 16$ in. $\times 16$ in. type are both comparable to the datum birch tea-chests; but the 18 in. $\times 12$ in. $\times 18 \mathrm{in}$. type is found to be slightly stronger than the 16 in. $\times 16$ in. $\times 16$ in. type, probably due to a more balanced construction of plywood. The teachest of ' $O$ ', 18 in. $\times 12$ in. $\times 18$ in. type, is, therefore, recommended as a standard, if making veneers of two different thicknesses is not considered a great disadvantage from the manufacturer's point of view. If 18 in. $\times 12$ in. $\times 18$ in. type is not considered convenient, then 16 in. $\times 16$ in. $\times 16$ in. type, which is the next best, can be established as the standard. There is no difference of any practical importance between the ' $O$ ' and ' $S$ ' types so far as strength is concerned.

\section{JOHN INNES HORTICULTURAL INSTITUTION}

$\mathrm{T}$ HERE is nothing merely formal or perfunctory, and much that is challenging, in the thirty-fifth annual report, for 1944, of the John Innes Horticultural Institution (from the Institution, Mostyn Road, Merton Park, London, S.W.19. 1945). Dr. C. D. Darlington, director of the Institution, has recently enunciated the hypothesis that "viruses of specific types can be created by grafting particular pairs of individuals". This is based on M. B. Crane's experiments on grafting the apple variety, Lord Lambourne, with other varieties. Lambourne may then become infected with two abnormalities'rubbery wood' and 'chat fruit'-deemed to be viruses. From the evidence presented in the report, it would seem that such infection could be explained by the assumption that Lambourne is completely susceptible to the two viruses, for which most apple varieties are symptomless carriers. The assumption that viruses are 'created' by the graft union seems at least a little ahead of the facts.

Mr. Crane and Dr. Lewis make the interesting suggestion of raising hybrid raspberries from seed, in order to eliminate virus from the initial stock. Preliminary experiments show satisfactory yields from hybrids, but many facets of the problem require consideration before hybrid seedling production can be regarded as a commercial proposition.

Dr. P. T. Thomas has found that 'bolters' in the potato crop possess an extra chromosome fragment which may presumably account for their premature flowering. Statistical technique has been applied by Dr. K. Mather to the analysis of behaviour and organization of polygenes. This provides more exact equipment for the plant breeder, and makes it possible to predict minimal selective limits, to relate the actual number of genes to their observed expression, and to determine whether hybrid vigour has reached the maximum.

The Institution has adopted the title, "Answers to Growers", for its first Bulletin (price 2s. 6d. from the Institution). Growers appear to have left the Institution in no doubt of their needs and, if their questions are such as to epitomize the work of the John Innes at present, that selection only allows of more factual and experimental answers. The grower is told that hoeing is of value for weed control rather than for moisture conservation; that composting tomato haulms does not destroy any virus they may carry; that the ultimate behaviour of his plants depends a good deal upon the character of the compost used for raising seedlings. Questions about the practical culture of sweet corn are answered. The particular and complex methods of hybrid seed production of this crop by top-crosses, double- and three-way crosses, and by synthetic varieties, are explained. The question, 'What are the best plums to grow ?', is answered by stating general principles - correct interplanting of dessert kinds (which are self- and cross-incompatible), the separation of highnectar varieties from those with low nectar, and the choice of frost-free sites, as plums flower early in the season. Some varieties of apple are shown to resist attack by red spider.

The Bulletin has achieved the right practical tone ; it is well produced, with a general series of photographs of experiments at the Institute, and the identity of the contributors is but thinly veiled by their initials. 